\title{
Telepraca - formy organizacyjne i możliwości rozwoju
}

https://doi.org/10.33141/po.2005.02.06

\section{Adam Birski}

Przegląd Organizacji, Nr 2 (781), 2005, ss. 26-30 www.przegladorganizacji.pl Towarzystwo Naukowe Organizacji i Kierownictwa (TNOiK)
Dynamiczny postęp, zwłaszcza w zakresie technik teleinformatycznych umożliwiający szybką i sprawną wymianę informacji na niemalże wszystkich poziomach życia gospodarczego i społecznego, zmienia sposób funkcjonowania i organizację wielu przedsiębiorstw i instytucji. Pogłębia się społeczny podział pracy, w wyniku którego powstają nowe formy organizacyjne prac oraz zróżnicowane możliwości ich wykonywania. Następują zmiany w klasycznym rozumieniu przestrzeni, miejsca i czasu pracy, co sprzyja systematycznej transformacji zarówno zawodów, jak i lokalizacji wykonywanej pracy. Nowe techniki wykonywania pracy umożliwiają ścisłą współpracę ludzi, mimo dzielącej ich przestrzeni i fizycznego oddalenia. Równocześnie zanikają stare, a pojawiają się nowe dotychczas nieznane zawody.

Przejawem rozwoju społeczeństwa informacyjnego i postępu organizacyjnego jest m.in. coraz większe zainteresowanie możliwością wykonywania pracy $\mathrm{w}$ formie tzw. telepracy - określanej również e-praca lub pracą zdalną (telework, teleworking, telecommuting). Ta nowa forma pracy rozwija się ostatnio również w Polsce, ale głównie w krajach zachodnich o utrwalonej gospodarce rynkowej, gdzie równocześnie warunki techniczne i ekonomiczne umożliwiają szybsze wkraczanie technik komputerowych i telekomunikacyjnych. Ponadto poszukiwane są bardziej konkurencyjne, lepiej dopasowane do rynku pracy oraz potrzeb przedsiębiorstw tzw. elastyczne formy pracy, do których zalicza się również telepracę [Bernais 2003, Birski 2003, Grudzewski, Hejduk 2000, Kordey 2003].

\section{Poziom i kierunki rozwoju telepracy w wybranych krajach Europy i USA}

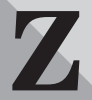

ainteresowanie tą elastyczną formą pracy w krajach zachodnich, a zwłaszcza w USA ${ }^{1)}$ ma już dość długą i co najmniej kilkunastoletnią tradycję, tym niemniej w ostatnich latach notuje wyraźne przyspieszenie. Odpowiednie znaczenie nadano pracy zdalnej w Unii Europejskiej2), gdzie w 1997 roku z inicjatywy Komisji Europejskiej powołano organizację pod nazwą European Telework Development (ETD). Rok później również w Polsce powstał polski Punkt Informatyczny ETD, a następnie serwis internetowy Telepraca Polska ${ }^{3)}$, gdzie rozwijana i wspieranajest idea telepracy. Szacuje się, że w Polsce telepracę na stałe wykonuje 1-2\% pracowników i około $8 \%$ sporadycznie ${ }^{4)}$. Tym niemniej w Polsce dotychczas nie prowadzono szczegółowych badań i nie ma kompleksowych danych dotyczących rozwoju tej formy pracy. Tymczsem najbardziej aktualne z 2002 roku dane dotyczące rozwoju telepracy w UE - 15 oraz w Szwajcarii i USA, pochodzą z raportu opracowanego przez jednostkę badawczą Empirica - Towarzystwo Badawcze Telekomunikacji i Technologii z siedzibą w Bonn ${ }^{5)}$.

W literaturze przedmiotu wyróżnia się kilka form organizacyjnych telepracy [N. Kordey, 2003; T. Metz, 2001; J. M. Nilles 1998; T.W. Malone, R.J. Laubacher, 1998; A. Najmiec, 2003; F. Pędziwiatr, 2002; J. Welsch, 1999]. Najczęściej jednak spotykane pojęcia i podziały w zasadzie pokrywają się z terminologią przyjętą przez Empiricę ${ }^{6}$. Zatem wyróżnia się trzy podstawowe formy: telepracę domową, mobilną i we własnym biurze. Telepraca domowa oznacza, że stanowisko pracy znajduje się w domu pracownika. W zależności od tego ile czasu spędza pracownik w domu, telepracę domową dzieli się na trzy rodzaje: stałą) (co najmniej $90 \%$ czasu pracy przypada na dom), przemienną (co najmniej 1 dzień w tygodniu pracownik przebywa w domu) i uzupełniającą (tylko niewielką część płatnej pracy wykonuje się w domu, mniej jednak niż 1 dzień w tygodniu).

Telepraca mobilna występuje wówczas, jeśli pracownik co najmniej 10 godzin w tygodniu pracuje poza miejscem pracy (np. w podróży służbowej) i ma możliwość internetowego połączenia ze swoim przedsiębiorstwem.

Telepraca we własnym biurze (tzw.SOHOs - small office, home office) ma miejsce $\mathrm{w}$ przypadku samozatrudnienia pracownika (praca na własny rachunek) i wykonywania większości prac w małym domowym biurze. Przy czym wszelkie kontakty biznesowe z klientami odbywają się głównie za pomocą połączeń on-line.

Biorąc pod uwagę powyższą klasyfikację relatywnie dużo osób mających poza miejscem stałej pracy dostęp do technologii internetowych może być zaliczonych do telepracowników. Według tej metodyki również piszącego artykuł pracownika naukowego, czy też dziennikarza i przesyłającego opracowanie do redakcji drogą on-line $\mathrm{z}$ domowego komputera można zakwalifikować jako telepracownika (wykonującego telepracę uzupełniająca).

Niezależnie od tych uwag, telepraca ma w UE duże i coraz większe znaczenie (tab. 1). Zaobserwowano bowiem stosunkowo wysoki i dynamicznie rosnacy w porównywanym okresie przeciętny udział telepracowników (6\% w 1999 i aż 13\% w 2002 roku) w ogólnej liczbie zatrudnionych. Najwyższe średnioroczne tempo wzrostu odnotowano $\mathrm{w}$ odniesieniu do pracy 
we własnym biurze $(55,7 \%)$. Relatywnie wysoka dynamika wzrostu odnosi się też do telepracy mobilnej $(38,7 \%)$ oraz uzupełniajaccej $(38,4 \%)$. Natomiast telepraca stała i przemienna pozostawała praktycznie na niewiele zmienionym poziomie $(1,7 \%)^{8}$.

Stopień zaawansowania różnych form telepracy w poszczególnych krajach UE-15 oraz w USA i Szwajcarii był bardzo zróżnicowany (tab. 2). Praktycznie we wszystkich formach telepracy, łącznie z praca zdalną ogółem, wyróżniały się przede wszystkim takie kraje, jak Holandia, Finlandia i Dania spośród należących do UE oraz USA. Przy czym Holandia spośód wszystkich ocenianych krajów dominuje ponadto wyraźnie w zakresie wykonywania telepracy domowej stałej i przemiennej. Wynika to niewątpliwie ze znanego faktu dużej otwartości społeczeństwa holenderskiego i zaawansowanego poziomu rozwoju tech- nologii informatycznych. To wszystko sprzyja szybszej akceptacji również nowych innowacyjnych technik wykonywania pracy. Z kolei najmniej omawiana forma elastycznej pracy była obecna w krajach Europy południowej, a zwłaszcza Portugalii i Hiszpanii. Na uwagę zasługuje również stosunkowo duża popularność telepracy mobilnej w takich krajach, jak: Szwajcaria, Finlandia i USA. Natomiast zdalną pracę we własnym biurze, dającą największą autonomię i niezależność najbardziej sobie cenili pracujący w USA, Austrii i Niemczech (tab. 2).

\section{Możliwości i ograniczenia rozwoju telepracy}

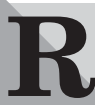

ozwój telepracy w UE ma związek nie tylko z wysokim poziomem rozwoju gospodarczego, a w tym telekomunikacji i informatyki.

Tab. 1. Rozwój form telepracy w UE-15 w latach 1999-2002

\begin{tabular}{|l|c|c|c|}
\hline \multirow{2}{*}{$\begin{array}{c}\text { Formy organizacyjne } \\
\text { telepracy }\end{array}$} & \multicolumn{2}{|c|}{ Udział telepracowników jako \% ogólu zatrudnionych } & \multirow{2}{*}{$\begin{array}{c}\text { Roczna dynamika } \\
\text { wzrostu w \% }\end{array}$} \\
\cline { 2 - 3 } & $\mathbf{1 9 9 9}$ & $\mathbf{2 0 0 2}$ & 1,7 \\
\hline Stała i przemienna & 2,0 & 2,1 & 38,4 \\
\hline Uzupełniająca & 2,0 & 5,3 & 38,7 \\
\hline Mobilna & 1,5 & 4,0 & 55,7 \\
\hline Własne biuro & 0,9 & 3,4 & 29,4 \\
\hline Ogółem & 6,0 & 13,0 & \\
\hline
\end{tabular}

Źródło: opracowanie własne na podstawie Empirica 2002.

Tab. 2. Formy organizacyjne telepracy jako \% ogółu zatrudnionych w wybranych krajach w 2002 roku

\begin{tabular}{|c|c|c|c|c|c|c|}
\hline \multirow[b]{2}{*}{ Kraj } & \multicolumn{3}{|c|}{ Telepraca domowa } & \multirow{2}{*}{$\begin{array}{c}\text { Telepraca } \\
\text { mobilna }\end{array}$} & \multirow{2}{*}{$\begin{array}{c}\text { Telepraca } \\
\text { we własnym } \\
\text { biurze }\end{array}$} & \multirow{2}{*}{$\begin{array}{c}\text { Telepraca } \\
\text { ogółem }\end{array}$} \\
\hline & $\begin{array}{c}\text { Stała } \\
\text { i przemienna }\end{array}$ & $\begin{array}{l}\text { Uzupe1- } \\
\text { niająca }\end{array}$ & Razem & & & \\
\hline Austria & 2,0 & 4,7 & 6,7 & 3,7 & 5,7 & 13,8 \\
\hline Belgia & 2,2 & 5,3 & 7,5 & 2,4 & 2,5 & 10,6 \\
\hline Dania & 2,6 & 15,1 & 17,7 & 2,7 & 2,9 & 21,5 \\
\hline Finlandia & 4,7 & 11,0 & 15,7 & 6,2 & 3,2 & 21,8 \\
\hline Francja & 2,2 & 2,3 & 4,5 & 2,1 & 0,8 & 6,3 \\
\hline Grecja & 2,1 & 3,9 & 6,0 & 3,5 & 3,4 & 11,1 \\
\hline Hiszpania & 0,3 & 2,0 & 2,3 & 0,8 & 2,0 & 4,9 \\
\hline Holandia & 9,0 & 11,6 & 20,6 & 4,1 & 5,0 & 26,4 \\
\hline Irlandia & 0,5 & 5,5 & 6,0 & 4,2 & 3,3 & 10,9 \\
\hline Niemcy & 1,6 & 6,3 & 7,9 & 5,7 & 5,2 & 16,6 \\
\hline Luksemburg & 0,9 & 2,4 & 3,3 & 1,5 & 1,8 & 5,6 \\
\hline Portugalia & 0,5 & 1,1 & 1,6 & 0,3 & 1,5 & 3,4 \\
\hline Szwecja & 5,3 & 9,5 & 14,8 & 4,9 & 2,0 & 18,7 \\
\hline Wlk. Bryt. & 2,4 & 8,5 & 10,9 & 4,7 & 4,5 & 17,3 \\
\hline Włochy & 0,8 & 1,7 & 2,5 & 5,5 & 2,6 & 9,5 \\
\hline UE 15 & 2,1 & 5,3 & 7,4 & 4,0 & 3,4 & 13,0 \\
\hline Szwajcaria & 4,2 & 7,1 & 11,3 & 7,6 & 2,2 & 16,8 \\
\hline USA & 5,1 & 12,2 & 17,3 & 5,9 & 6,3 & 24,6 \\
\hline
\end{tabular}

Źródło: opracowanie własne na podstawie Empirica 2002. 
Wynika to także $\mathrm{z}$ faktu, że w UE nowe rozwiązania w zakresie elastycznych form pracy znajdują także stosunkowo szybko odzwierciedlenie w odpowiednich przepisach. Ponadto w kształtowaniu systemów prawnych UE ma doświadczenie w kojarzeniu interesów różnych grup społecznych i politycznych oraz unikaniu konfliktów. Z drugiej jednak strony należy przyznać, że w UE brak jest wyodrębnionych regulacji prawnych w odniesieniu wyłącznie do telepracy. Sa natomiast szerzej sformułowane przepisy odnoszące się do tzw. nietypowego czasu pracy (dyrektywa 97/ 812/WE) oraz w zakresie bezpieczeństwa i zdrowia pracowników zatrudnionych tymczasowo lub na czas określony (dyrektywa 91/383/WE). Jednak pracownicy wykonujący zadania w formie telepracy są chronieni przez odpowiednie zapisy w kodeksach pracy, gdzie zawarte są przepisy dotyczące pracowników pracujących w domu lub innym wybranym miejscu, bądź pracujących w systemie zadaniowym. Najbardziej szczególowo te zagadnienia traktują lokalne samorządy bądź przedsiębiorstwa, w ramach zbiorowych umów pracowniczych. Najdalej kwestie telepracy zostały uregulowane we Włoszech, Irlandii, Holandii, Belgii i Danii, gdzie pracodawcy znacząco partycypują w kosztach wyposażenia i utrzymywania domowego biura.

Znaczący postęp w regulacjach prawnych w odniesieniu do zdalnej pracy obserwujemy także w Polsce. W obowiązujacym po nowelizacji od 1 stycznia 2004 roku kodeksie pracy, co prawda nie użyto nigdzie terminu telepraca, to jednak zapis w art. 140 mówiący o zadaniowym czasie pracy dopuszcza jej stosowanie „uzasadnione rodzajem pracy lub jej organizacją, albo miejscem wykonywania". Zadaniowość pracy nie wymaga ewidencjonowania pracy i konstrukcji szczegółowych harmonogramów rozliczania czasu pracy i jest w związku z tym wygodną formą dla pracodawców, zwłaszcza tych zamierzających stosować elastyczne formy pracy.

Stosunkowo najłatwiej, nie ma bowiem praktycznie ograniczeń prawno-organizacyjnych, można stosować telepracę we wszystkich działalnościach prowadzonych na własny rachunek, przy aktywnym oczywiście wykorzystaniu technik telekomunikacyjnych i informatycznych. Lista tych prac i zawodów jest bardzo długa i systematycznie się powiększa ${ }^{9}$.

Szczególnym przykładem pracy w Polsce, która przerodziła się w ostatnim okresie (stosunkowo niedawno, bowiem od 2001 roku) z pracy w tradycyjnym rozumieniu w telepracę domową jest zawód maklera giełd towarowych. Technika teleinformatyczna spowodowała przekształcenie dotychczasowego systemu tzw. giełd parkietowych w giełdę elektroniczną. $\mathrm{Na}$ tych pierwszych podczas niemalże codziennych sesji (przetargów bądź licytacji) niezbędna była obecność maklerów reprezentujących swoich kontrahentów chcaccych sprzedać, bądź zakupić określony towar. Elektroniczny system zakupów zastosowany dla przykładu na Warszawskiej Giełdzie Towarowej od 2001 roku, przy jednoczesnym skoncentrowaniu wyłacznie na niej handlu towarami pochodzącymi z zakupów interwencyjnych i rezerw państwowych w jednym miejscu, umożliwił powszechny dostęp do towarów w tym samym czasie wszystkim uprawnionym do zaku- pu biurom maklerskim ze swoich siedzib zlokalizowanych w różnych regionach kraju (a nawet świata w przypadku wielkich towarowych giełd światowych). Zastosowane coraz powszechniej powyższe rozwiązania prowadza do obniżenia kosztów funkcjonowania biur maklerskich, zwłaszcza tych regionalnych, ich przedstawiciele nie muszą bowiem kilka razy w tygodniu być fizycznie obecni na giełdzie, a pracują w domowym bądź wynajętym biurze w miejscu zamieszkania. W tych nowych warunkach każdy makler akredytowany na danej giełdzie $\mathrm{z}$ dowolnego miejsca może zakupić lub sprzedać dowolną transzę wystawianego towaru w przypadku zaoferowania najwyższej lub odpowiednio najniższej ceny, która nie zostanie przelicytowana w ciągu ściśle określonego czasu (np. ostatnich 60 sekund). Zatem podobnie jak w klasycznym systemie tzw. parkietowym ma miejsce licytacja, ale odbywa się ona drogą elektroniczną poprzez internet [Birski, 2003].

Przystapienie Polski do UE oraz otwarcie rynków pracy w niektórych krajach 15 (np. w Wielkiej Brytanii, Irlandii, Szwecji) stworzyło bez wątpienia nowe perspektywy przed wieloma polskimi pracownikami. Natomiast mniej oczywisty jest fakt, że stopniowa ewolucja gospodarki w kierunku nowej ekonomii, a w zasadzie ekonomii on-line sprawia, że miejscowe, regionalne zasoby pracy wyposażone $\mathrm{w}$ odpowiednią wiedzę, zaczynają odgrywać rolę jako element coraz szerszego rynku pracy, wykraczajaccego poza granice państwowe i obszary językowe, a nawet systemy gospodarcze i kontynenty. Należy widzieć tutaj coraz większą szansę dla kraju takiego, jak Polska, z trudnymi do rozwiązania społecznymi problemami wysokiego poziomu bezrobocia. Barierą przestaje być bowiem przestrzeń, geograficzna odległość, czy też granice administracyjno-polityczne, a stają się nimi tylko odpowiednie kwalifikacje merytoryczne, a w przypadku eksportu usług także znajomość odpowiednich języków obcych. Co prawda nie obejmują tego oficjalne statystyki, ale jak wynika z dotychczasowych obserwacji i studiów przypadków, coraz częściej firmy komputerowe z krajów zachodnich, w tym zwłaszcza z USA, korzystają z usług (np. przy tworzeniu stron internetowych, pisaniu programów etc.) tańszych, wysoko kwalifikowanych i bardziej dyspozycyjnych informatyków z krajów słabiej rozwiniętych gospodarczo. I to nie tylko polskich, ale również czeskich, węgierskich, rosyjskich, ukraińskich, hinduskichetc. Przy czym wszystkie relacje w ramach stosunków pracy odbywają się zdalnie, począwszy od nawiązania kontaktów i zawarcia stosownej umowy, a skończywszy na rozliczeniu honorariów.

\section{Telepraca w telecentrach - nowa polska specjalność}

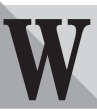

Polsce w ostatnim okresie zaczyna się dynamicznie rozwijać inna forma telepracy - praca w tzw. telecentrach (call center $)^{10)}$. Firmy tego typu oferuja bardzo szeroki wachlarz usług m.in. takich, jak: telemarketing, obsługa infolinii, a także budowa baz danych, prowadzenie akcji promocyjnych, szkolenie telemarketerów, pomoc w organizacji działów telemarketingowych w przedsiębiorstwach, bada- 
nia budżetów klientów, badania satysfakcji klientów $\mathrm{i}$ inne usługi związane $\mathrm{z}$ badaniem rynku. Zatem telecentra pełnią rolę swoistych centrów obsługi klienta. Zarówno w polskich telecentrach (np. Call Center Poland), jak i w tych będących oddziałami międzynarodowych koncernów i korporacji, dzięki wykonywaniu zdalnej pracy obsługiwani są nie tylko klienci krajowi, ale coraz częściej zagraniczni i to nie tylko z Europy. W tych warunkach ma miejsce postępująca w coraz większej skali koncentracja niektórych usług, które mogą być realizowane w jednym miejscu dla klientów, niezależnie od ich miejsca zamieszkania. Szczególne zainteresowanie Polską nastąpiło po przystąpieniu naszego kraju do UE. Atrakcyjność Polski w tym względzie wynika $\mathrm{z}$ wielu znanych przesłanek (położenie geograficzne, dynamika rozwoju, klimat inwestycyjny etc.), ale przede wszystkim z faktu stosunkowo dużej podaży relatywnie wysoko wykwalifikowanych pracowników z odpowiednią znajomością języków obcych. W przypadku podejmowania decyzji o zainwestowaniu kapitału w przedsięwzięcie celem wykonywania pracy zdalnej nie mają tak dużego znaczenia inne elementy atrakcyjności inwestycyjnej, takie jak infrastruktura drogowa i szerzej komunikacyjna, bardzo ważne przy decyzjach o lokalizacji tradycyjnych działalności opartych na szeroko rozumianej logistyce ${ }^{11)}$. Niektóre organizacje z kapitałem zagranicznym tworzą tutaj swoje oddziały od podstaw, tak jak firma Arvato Services (oddział koncernu Bertelsmanna z siedziba w Niemczech) w Szczecinie, czy Transcom (międzynarodowa korporacja świadcząca różnorodne usługi w zakresie marketingu, finansów, telekomunikacji, e-sprzedaży, CRM etc. z siedziba w Luksemburgu) w Olsztynie ${ }^{12}$. Inne z kolei podejmuja decyzje o wykupieniu części kapitału w funkcjonujących już z dobrym skutkiem polskich przedsiębiorstwach, np. większościowym posiadaczem polskiej spółki CTM Centrum Telemarketingowe z siedzibą w Warszawie (300 stanowisk pracy) została firma SR Teleperforman$\mathrm{ce}^{13)}$. Ponadto na zasadach pracy zdalnej już rozpoczęło działalność w bieżącym roku Europejskie Centrum Usługowe Phillipsa w Łodzi, świadczące usługi finansowo-księgowe ${ }^{14)}$. Docelowo będzie ono najważniejszym centrum usługowym tego koncernu w Europie. Zatem o lokalizacji tego typu centrów przesądza głównie bliskość odpowiednich zasobów pracy (a nie bliskość aktualnych, czy potencjalnych klientów, jak w przypadku tradycyjnych działalności), chociaż i inne kwestie, jak chociażby podatkowe w danym kraju też odgrywają znaczącą rolę.

dr Adam Birski

Katedra Ekonomiki Przedsiębiorstw Wydział Nauk Ekonomicznych

Uniwersytet Warmińsko-Mazurski w Olsztynie

\section{PRZYPISY}

1) Stosunkowo wyczerpujące opracowanie dotyczące różnych aspektów organizacyjno-społecznych telepracy w USA, to ksiażka autorstwa Niellsa uważanego za prekursora tej formy pracy. Jack M. NILLES, 1998, Managing Telework. Strategies for Managing the Virtual Workforce.

2) W 2001 roku powstał szczegółowy raport pt. Flexible Working Handbook autorstwa C. Selby, F. Wilson, W. Korte, J. Millard, W. Carter, jako efekt wykonania projektu pt.
FlexWork, realizowanego w ramach 5. Programu Ramowego Badań i Rozwoju Technologicznego UE. Aktualnie polską wersję (tłum. P. Młynarek i A. Turowiec) tego raportu pt. Almanach wiedzy o telepracy można znaleźć na stronie internetowej http://www.flexwork.eu.com. Raport ma na celu upowszechnienie praktycznych informacji i narzędzi dotyczących telepracy, zwłaszcza wśród małych i średnich przedsiębiorstw w krajach UE.

${ }^{3)} \mathrm{http}$ //www.telepraca-polska.pl.

4) Przez co najmniej jedną czwartą czasu pracy; wg raportu Europejskiej Fundacji na rzecz Poprawy Warunków Życia i Pracy pt. Warunki pracy $w$ krajach przystęujacych $i$ kandydujacych, http://www.eurofound.eu.int.

5) Badania dotyczace telepracy wykonano w 2002 roku w ramach projektu SIBIS (Statistical Indicators Benchmarking the Information Society), finansowanego przez Unię Europejską na reprezentatywnej próbie 11832 osób. Raport pt. Verbreitung der Telearbeit in 2002. Internationaler Vergleich und Entwicklungstendenzen znajduje się na stronie internetowej http://www.empirica.com. Badania te były kontynuacją wcześniej przeprowadzonych w 1999 roku badań realizowanych w ramach projektu EcaTT (Electronic Commerce and Telework Trends).

6) Op.cit., s. 4.

7) Wykonywanie stałej telepracy domowej należało do rzadkości, głównie z uwagi na podstawowy mankament tej formy pracy, tj. izolację społeczną pracownika; tylko zaledwie $3,1 \%$ wykonujacych teleprace domowa $75 \%$ czasu pracy spędzało w domu. Por. Verbreitung der Telearbeit in $2002 \ldots$, op.cit., s. 12.

8) Należy wyjaśnić, że suma poszczególnych form telepracy jest wyższa od telepracy ogółem, co wynika z faktu, że w przeprowadzanych badaniach nie uniknięto wzajemnego krzyżowania i nakładania się różnych odmian pracy zdalnej, a zwłaszcza telepracy mobilnej z pozostałymi, op.cit., s. 11

9) Do najważniejszych prac można zaliczyć, zaczynając od tych wymagających najwyższych kwalifikacji informatycznych: programowanie komputerowe, projektowanie stron www, wykonywanie grafiki komputerowej i bitowej, wyszukiwanie danych i tworzenie baz danych, elektroniczne przetwarzanie danych, prace projektowe, doradztwo, usługi księgowo-finansowe, usługi edukacyjne, a zwłaszcza zdalne nauczanie, badania socjologiczne i marketingowe, prace maklerów elektronicznych giełd towarowych, różne formy prac twórczych (pisarze, naukowcy, dziennikarze), różnego rodzaju prace redakcyjne, wykonywanie zawodu telemarketera, prowadzenie sklepów internetowych, inne prace związane $\mathrm{z}$ szeroko rozumianą informacja etc., szerzej w poz. bibl. [ 3].

10) Nie ma szczegółowych informacji liczbowych na temat tej formy pracy $\mathrm{w}$ oficjalnej statystyce UE. W cytowanym wyżej raporcie Empirica analizowano jedynie potencjalne zainteresowanie pracujacych i bezrobotnych aktywnością $\mathrm{w}$ różnych formach telepracy, w tym w telecentrach.

11) Według najnowszego raportu z 13 kwietnia 2004 roku niemieckiej agencji konsultingowej A.T. Kearney, ustalającego ranking krajów pod względem atrakcyjności lokowania jednostek typu Call Center, Polska znalazła się na 10. miejscu wśród 25 uznanych za atrakcyjne pod tym względem krajów. Na pierwszych trzech miejscach znalazły się kraje azjatyckie, takie jak: Indie, Chiny i Malezja, głównie z uwagi na niskie koszty pracy. Spośród krajów europejskich wyprzedziły nas tylko Czechy (4. miejsce), a za nami uplasowały się Węgry (11.), Portugalia (19.), Rosja (21.), Hiszpania (22.) i Irlandia (23.). Szczegółowe informacje na ten temat w artykule pt. Kostensenkung allein ist kein Grund für Offshoring na stronie internetowej http://www.atkearney.de/content/presse. 
12) Transcom posiada łącznie 33 oddziały w 18 krajach, głównie Europy zachodniej, a także od kilku lat w Estonii, Litwie, Łotwie, a ostatnio od 2003 roku również w Polsce (Olsztyn). Klient Transcomu w zależności od rodzaju zgłaszanych swoich potrzeb i życzeń, jest po zalogowaniu się automatycznie kierowany do obsługi przez odpowiedni merytorycznie i językowo oddział (niezależnie od jego geograficznej lokalizacji) i najbardziej kompetentnego pracownika.

13) Teleperformance zajmuje się zintegrowanymi usługami zarządzania relacjami z klientem, w tym pozyskiwaniem klienta, obsługą klienta oraz programami rozwoju relacji z klientem. Cała korporacja posiada na terytorium 32 państw (w tym m.in. Czech i Słowacji), w swoich 137 centrach obsługi, około 26500 komputerowych stanowisk pracy, realizujących usługi w 30 językach. Więcej szczegółowych informacji na stronie internetowej; www.srteleperformance.com.

14) Jak wynika z danych Polskiej Agencji Informacji i Inwestycji Zagranicznych dalszych kilkanaście firm międzynarodowych zastanawia się nad utworzeniem w naszym kraju różnego typu jednostek usługowych. W przypadku zrealizowania tych inwestycji Polska ma szansę przekształcić się w europejskie centrum usług outsourcingowych. Informacje na temat zainteresowania kapitału zagranicznego inwestycjami w Polsce znajdują się na stronie internetowej http://www.paiz./index.php.

\section{BIBLIOGRAFIA}

[1] BERNAIS J., Elastyczne formy zarzadzania zasobami ludzkimi we wspótczesnych organizacjach, „Przegląd Organizacji" 5/2003.

[2] BIRSKI A., Stan i perspektywy rozwoju gietd towarowych $w$ Polsce na tle doświadczeń zagranicznych. Cześć I - Rynek gotówkowy, „Zagadnienia Ekonomiki Rolnej” 4/2003.

[3] BIRSKI A., Nowoczesne formy pracy szansa aktywizacji obszarów wiejskich $w$ Polsce po przystapieniu do UE, „Prace Naukowe AE we Wrocławiu", nr 1015, 2004.

[4] GAREIS K., HÜSING T., MÜLLER S., Multi-locational Work and the Region, [w:] PAUL CUNNINGHAM et al. (red.), Building the Knowledge Economy. Issues, Applications, Case Studies, Part 2, IOS Press, Amsterdam/Berlin 2003.

[5] GRUDZEWSKI W.M., HEJDUK J.K., Charakterystyka organizacji wirtualnej, [w:] Przedsiębiorstwo przyszłości, red. W.M. Grudzewski, J.K. Hejduk, Difin 2000.

[6] KORDEY N., Telearbeit. Erfolgsfaktoren für mehr Flexibilität, „Personalwirtschaft” 2003, z. 11.

[7] MALONE T.W., LAUBACHER R.J., The Dawn of the ELance Economy, „Harvard Business Review”, wrzesień/październik 1998.

[8] MERTENS P., HARTMANN P., FAISST W., Virtuelle Unternehmen - Virtuelle Staaten: Polarisierung in diesem Jahrhundert?, „Industrie Management”, 16/2000.

[9] METZ T., Telearbeit - technologische Träume und organisations-theoretische Perspektiven, „ZFO” 70, z. 2/2001.

[10] NAJMIEC A., Psychologiczne, spoteczne $i$ organizacyjne uwarunkowania telepracy, „Bezpieczeństwo Pracy” $1 / 2003$.

[11] NILLES J.M., Managing Telework. Strategies for Managing the Virtual Workforce, 1998.

[12] PECDZIWIATR F., Telepraca $i$ jej implikacje, „Zarządzanie Zasobami Ludzkimi”, 2/2002.

[13] WELSCH J., 1999, Telearbeit - Arbeitsform der Wissensgesellschaft, www.flexible-unternehmen.de/kl0903.htm (2004.04.18).

[14] WINKER G., MAUS B., Telearbeit - Chancen für eine bessere Integration beruflicher und familiarer Lebensbereiche, FIFF-Komunikation 4/2000. 